\title{
Respon Pemberian Pupuk Rock Phosphate terhadap Pertumbuhan Biji Kecambah Kelapa Sawit (Elaeis guineensis Jacq)
}

\author{
Response of Rock Phosphate Fertilizers on Growth of Palm Oil \\ (Elaeis guineensis Jacq) Sprout Seeds \\ Daryono $^{1 *}$, Haryatie Sarie ${ }^{2}$ \\ ${ }^{1}$ Program Studi Budidaya Tanaman Perkebunan, Politeknik Pertanian Negeri Samarinda, \\ Samarinda, Indonesia \\ ${ }^{2}$ Program Studi Pengelolaan Lingkungan, Politeknik Pertanian Negeri Samarinda, Samarinda, \\ Indonesia. \\ *Corresponding author: ydaryono16@yahoo.com.
}

\begin{abstract}
ABSTRAK
Penelitian ini bertujuan untuk mengetahui pengaruh dosis pupuk kimia rock phosphate yang terbaik terhadap pertumbuhan bibit kelapa sawit (Elaeis guineensis Jacq) di pembibitan awal biji kecambah prenursery. Penelitian ini terdiri dari satu perlakuan yaitu pemberian pupuk rock posphate yang terdiri dari tiga taraf yaitu $\mathrm{P}_{0}$ : Dosis $5 \mathrm{~g}$ pupuk RP/tanaman, $\mathrm{P}_{1}: 10 \mathrm{~g}$ pupuk RP/tanaman dan $\mathrm{P}_{2}: 15 \mathrm{~g}$ pupuk RP/tanaman. Penelitian ini menggunakan Rancangan Acak Lengkap (RAL) terdiri 3 taraf dan setiap taraf di ulang sebanyak 20 ulangan (tanaman). Sehingga jumlah tanaman yang di amati sebanyak 60 tanaman. Hasil penelitian menunjukan bahwa pengamatan waktu muncul tunas tidak memberikan pengaruh beda nyata pada semua perlakuan P1, P2 dan P3. Pengamatan Jumlah daun umur 30 hst tidak berbeda nyata sedangkan umur 60 dan 90 memberikan pengaruh beda nyata pada semua perlakuan P1, P2 dan P3. Pada dosis $10 \mathrm{~g} /$ tanaman untuk umur 60 hst rata-rata 2,65 helai, dosis $15 \mathrm{~g} /$ tanaman umur 90 hst rata-rata 3,93 helai. Pengamatan tinggi tanaman umur $30 \mathrm{hst}$ tidak berbeda nyata sedangkan umur 60 berpengaruh beda nyata pada dosis $10 \mathrm{~g} /$ tanaman rata-rata $19,65 \mathrm{~cm}$ dan umur $90 \mathrm{hst}$ berbeda nyata pada dosis $15 \mathrm{~g} /$ tanaman rata-rata $20,00 \mathrm{~cm}$. Pengamatan diameter batang umur 60 hst tidak berbeda nyata sedangkan umur $90 \mathrm{hst}$ memberikan pengaruh beda nyata pada dosis $15 \mathrm{~g} /$ tanaman rata-rata $0,30 \mathrm{~mm}$.
\end{abstract}

Kata Kunci : Pupuk Rock Phosphate, Pertumbuhan, Biji Kecambah Kelapa Sawit.

\section{ABSTRACT}

This study aims to determine the effect of the best dose of rock phosphate chemical fertilizer on the growth of oil palm seedlings (Elaeis guineensis Jacq) in the initial seedling of pre-nursery sprouts. This study consisted of 1 treatment, namely rock phosphate fertilizer consisting of 3 levels, namely P0: Dose $5 \mathrm{~g}$ of RP / plant fertilizer, P1: $10 \mathrm{~g}$ of RP / plant fertilizer and P2: $15 \mathrm{~g}$ of RP / plant fertilizer. This research uses a Completely Randomized Design (CRD) consisting of 3 levels and each level is repeated as many as 20 replications (plants). So that the number of plants observed was 60 plants. The results showed that observations of time of emergence of shoots did not have a significantly different effect on all treatments $P 1$, $P 2$ and $P 3$. Observation The number of leaves aged 30 HST was not significantly different while the ages of 60 and 90 had a significant effect on all treatments P1, P2 and P3. At the dose of $10 \mathrm{~g} /$ plant of 60 HST the average was 2.65 strands, while at the dose of $15 \mathrm{~g} /$ plant of $90 \mathrm{HST}$ the average was 3.93 strands. Observation of plant height at 30 days after planting was not significantly different while age 60 had a significantly different effect on doses of $10 \mathrm{~g} /$ plant on average $19.65 \mathrm{~cm}$ and age of 90 days after planting was significantly different at doses of $15 \mathrm{~g} /$ plant with average of $20.00 \mathrm{~cm}$. Observation of stem diameter of 60 DAP was not significantly different while 90 DAP had a significantly different effect at a dose of $15 \mathrm{~g} /$ plant on average $0.30 \mathrm{~mm}$.

Keywords : Rock Phosphate Fertilizer, Growth, Palm Oil Seed Sprouts.

\section{PENDAHULUAN}

Tanaman kelapa sawit (Elaeis guineensis Jacq.) merupakan tanaman yang berkembang di Indonesia dan salah satunya Propinsi Kalimantan Timur merupakan daerah pengembangan perkebunan kelapa sawit dan penghasil minyak nabati yang telah menjadi komoditas pertanian utama dan unggulan di Indonesia. Perkebunan kelapa sawit merupakan sumber pendapatan bagi jutaan keluarga petani, sumber devisa negara, penyedia lapangan kerja, serta sebagai pendorong tumbuh dan berkembangnya industri hilir berbasis 
minyak kelapa sawit di Indonesia (Nu'man, 2009).

Faktor utama yang mempengaruhi produktivitas tanaman di perkebunan kelapa sawit yaitu penggunaan bibit yang berkualitas. Selain penggunaan bibit unggul di pembibitan, pemeliharaan bibit juga harus mendapat perhatian terutama yang berkaitan dengan pemupukan. Menurut Winarna dan Sutarta (2003), upaya-upaya untuk meningkatkan efektivitas dan efisiensi pemupukan perlu terus dilakukan agar produktivitas tanaman dapat ditingkatkan. Beberapa upaya yang dapat dilakukan antara lain melalui perbaikan ketepatan pemilihan dan aplikasi pupuk, penggunaan pupuk dasar sebagai sumber hara pada tanaman.

Pembibitan merupakan suatu hal penting dalam bubidaya tanaman kelapa sawit, pertumbuhan awal bibit merupakan periode kritis yang sangat menentukan keberhasilan tanaman dalam mencapai pertumbuhan yang baik di pembibitan.Salah satu upaya yang dapat dilakukan selama pembibitan awal pre-nursery tanaman kelapa sawit tersebut yaitu dengan pemberian pupuk dasar. Dengan memakai pupuk dasar rock posphate, gejala-gejala tanaman kerdil dan masalah pembuahan dapat diperbaiki. Pemakaian pupuk rock poshate sebaiknya pada awal pertumbuhan atau sebagi pupuk dasar dan sebelum pembungaan.

\section{BAHAN DAN METODE}

Penelitian ini dilaksanakan mulai pada bulan Agustus sampai bulan Desember 2019 mulai dari penyediaan bahan dan alat, Aplikasi perlakuan, pengamatan, pengolahan data dan pembuatan laporan. Sedangakan tempat yang gunakan untuk pelaksanaan penanaman biji kecambah kelapa sawit di Losbayangan Laboratorium Agronomi dan Laboratorium Percontohan Program Studi Budidaya Tanaman Perkebunan Politeknik Pertanian Negeri Samarinda Kec. Samarinda Seberang Kota Samarinda Kalimantan Timur. Alat yang digunakan dalam penelitian adalah :sabit, timbangan analitik, gelas ukur, gelas aqua, Mikro kalifer digital, ayakan tanah, skop kecil, gembor, springkel,ember kecil,kamera dan alat tulis.Bahan yang digunakan dalam penelitian ini Biji kecambah kelapa sawit,tanah top soil, pupuk rock posphate, Baby baq kecil ukuran l:14 x p:23 cm $x$ $\mathrm{t}: 0,1 \mathrm{~mm}$.

Rancangan Percobaan penelitian ini terdiri dari 1 perlakuan yaitu pemberian pupuk rock posphate yang terdiri dari 3 taraf: $\mathrm{P}_{1}$ (dosis $5 \mathrm{~g}$ pupuk RP/tanaman), $\mathrm{P}_{2}$ (dosis $10 \mathrm{~g}$ pupuk RP/tanaman), $P_{3}$ (dosis $15 \mathrm{~g}$ pupuk RP/tanaman). Penelitian ini menggunakan Rancangan Acak Kelompok (RAK) terdiri 3 taraf dan setiap taraf di ulang sebanyak 20 ulangan (tanaman). Setiap kelompok di acak dengan cara di undi. Sehingga jumlah tanaman yang di amati sebanyak 60 tanaman.

Prosedur penelitian: a) Persiapan bahan biji kecambah kelapa sawit, b) pengambilan media tanah, c) pengayakan media tanah, d) pengisian baby bag, e) pemberian pupuk rock phosphate, f) pemeliharaan biji kecambah kelapa sawit.

Metode pengambilan data: 1) Waktu Tumbuh Tunas (Hari) Pengamatan dimulai 13 hari setelah tanam dan pengamatan setiap hari, 2) Jumlah daun bibit kelapa sawit pre-nursery umur 30, 60 dan 90 hari setelah tanam, 3) Tinggi bibit kelapa sawit pre-nursery umur 30, 60 dan 90 hari setelah tanam, 4) Diameter batang bibit kelapa sawit pre-nursery umur 60 dan 90 hari setelah tanam.

\section{HASIL DAN PEMBAHASAN}

\section{Waktu Tumbuh Tunas (Hari)}

Berdasarkan hasil penelitian perlakuan kecambah bibit kelapa sawit dan pupuk rock phospat memberikan pengaruh tidak nyata pada semua pengamatan waktu tumbuh tunas umur 15, 16, 17, 18,19,20,21 dan 22 hari setelah tanam (hst).

\section{Jumlah Daun Bibit Kelapa Sawit (Pre- nursery)Umur 30, 60 dan 90 Hari Setelah Tanam (hst)}

a. Jumlah Daun Umur 30 hst

Berdasarkan hasil penelitian perlakuan kecambah bibit kelapa sawit dan pupuk rock phospat memberikan pengaruh tidak nyata pada jumlah daun umur 30 hari setelah tanam perlakuan $\mathrm{P} 1, \mathrm{P} 2$ dan $\mathrm{P} 3$.

b. Jumlah Daun Umur 60 hst

Berdasarkan tabel 1 di atas perlakuan biji kecambah kelapa sawit dan pupuk rock 
phospat jumlah daun umur 60 hari setelah tanam berpengaruh nyata pada perlakuan P1 terhadap perlakuan P2 dan P3.Sedangkan perlekuan P2 dan P3 tidak berbeda nyata.

c. Jumlah Daun Umur 90 hst

Berdasarkan tabel 2 di atas perlakuan biji kecambah kelapa sawit dan pupuk rock phospat jumlah daun umur 90 hari setelah tanam berpengaruh nyata pada perlakuan P3, P2 dan P1. Sedangkan P2 berpengaruh nyata pada perlakuan $\mathrm{P} 1$ dan $\mathrm{P} 3$, serta perlakuan $\mathrm{P} 1$ berbeda nyata pada perlakuan P2 dan P3.

Tabel 1. Rerata Jumlah daun umur 60 hst

\begin{tabular}{cccc}
\hline Pupuk Rock Phospat & Dosis 5 g/tanaman & Dosis $10 \mathrm{~g} /$ tanaman & Dosis $15 \mathrm{~g} /$ tanaman \\
\cline { 2 - 4 } & $P 1$ & $P 2$ & $P 3$ \\
\hline $\begin{array}{c}\text { Bibit } \\
\text { kelapa sawit } \\
\text { (Pre-nursery) }\end{array}$ & $2,2000 \mathrm{~b}$ & $2,6500 \mathrm{a}$ & $2,5000 \mathrm{a}$ \\
\hline
\end{tabular}

*Keterangan : Angka rata-rata yang diikuti dengan huruf yang sama menunjukkan tidak berbeda nyata pada taraf alpha $5 \%$ UJI BNT $(P)=0,30$

Tabel 2. Rerata Jumlah daun umur 90 hst

\begin{tabular}{cccc}
\hline Pupuk Rock Phospat & Dosis 5 g/tanaman & Dosis $10 \mathrm{~g} /$ tanaman & Dosis $15 \mathrm{~g} /$ tanaman \\
\cline { 2 - 4 } & $P 1$ & $P 2$ & $P 3$ \\
\hline $\begin{array}{c}\text { Bibit } \\
\text { kelapa sawit } \\
\text { (Pre-nursery) }\end{array}$ & $3,3000 \mathrm{c}$ & $3,6000 \mathrm{~b}$ & $3,9500 \mathrm{a}$ \\
\hline *Kenten
\end{tabular}

*Keterangan : Angka rata-rata yang diikuti dengan huruf yang sama menunjukkan tidak berbeda nyata pada taraf alpha $5 \%$ UJI BNT $(P)=0,26$

\section{Tinggi Bibit Kelapa Sawit (Pre-nursery) Umur 30, 60 dan 90 Hari Setelah Tanam (hst)}

a.Tinggi Bibit Tanaman Kelapa Sawit (Prenursery) Umur 30 hst

Berdasarkan hasil penelitian perlakuan kecambah bibit tanaman kelapa sawit dan pupuk rock phospat memberikan pengaruh tidak nyata pada Tinggi bibit kelapa sawit umur 30 hari setelah tanamuntuk perlakuan P1, P2 dan P3.

b. Tinggi Bibit Tanaman Kelapa Sawit (Prenursery) Umur 60 hst

Berdasarkan tabel 3 di atas perlakuan biji kecambah kelapa sawit dan pupuk rock phospat tinggi bibi tanaman kelapa sawit umur 60 hari setelah tanam berpengaruh nyata pada perlakuan P3, P2 dan P1. Sedangkan P2 berpengaruh tidak nyata pada perlakuan $\mathrm{P} 1$, serta perlakuan $\mathrm{P} 1$ berbeda nyata pada perlakuan P3.

c. Tinggi Bibit Tanaman Kelapa Sawit (Prenursery) Umur 90 hst

Berdasarkan tabel 4 di atas perlakuan biji kecambah kelapa sawit dan pupuk rock phospat tinggi bibi tanaman kelapa sawit umur 90 hari setelah tanam berpengaruh nyata pada perlakuan P1, P2 dan P3. Sedangkan P2 berpengaruh tidak nyata pada perlakuan $\mathrm{P} 3$, serta perlakuan $\mathrm{P} 3$ berbeda nyata pada perlakuan P1.

Tabel 3. Rerata Tinggi bibit kelapa sawit(Pre-nursery) umur $60 \mathrm{hst}$

\begin{tabular}{cccc}
\hline Pupuk Rock Phospat & Dosis 5 g/tanaman & Dosis $10 \mathrm{~g} /$ tanaman & Dosis $15 \mathrm{~g} /$ tanaman \\
\cline { 2 - 4 } & $P 1$ & $P 2$ & $P 3$ \\
\hline $\begin{array}{c}\text { Bibit } \\
\begin{array}{c}\text { kelapa sawit } \\
\text { (Pre-nursery) }\end{array}\end{array}$ & $13,2100 \mathrm{~b}$ & $13,4075 \mathrm{~b}$ & $19,6525 \mathrm{a}$ \\
\hline
\end{tabular}

${ }^{*}$ Keterangan : Angka rata-rata yang diikuti dengan huruf yang sama menunjukkan tidak berbeda nyata pada taraf alpha $5 \%$ UJI BNT $(P)=1,35$ 
Tabel 4. Rerata Tinggi bibit kelapa sawit (Pre-nursery) umur 90 hst

\begin{tabular}{cccc}
\hline Pupuk Rock Phospat & Dosis 5 g/tanaman & Dosis $10 \mathrm{~g} /$ tanaman & Dosis 15 g/tanaman \\
\cline { 2 - 4 } & $P 1$ & $P 2$ & $P 3$ \\
\hline $\begin{array}{c}\text { Bibit } \\
\text { kelapa sawit } \\
\text { (Pre-nursery) }\end{array}$ & $17,7600 \mathrm{~b}$ & $19,6525 \mathrm{a}$ & $20,0025 \mathrm{a}$ \\
\hline
\end{tabular}

${ }^{*}$ Keterangan : Angka rata-rata yang diikuti dengan huruf yang sama menunjukkan tidak berbeda nyata pada taraf alpha $5 \%$ UJI BNT $(P)=1,36$

Tabel 5. Rerata diameter batang bibit kelapa sawit(Pre-nursery) umur 90 hst

\begin{tabular}{cccc}
\hline Pupuk Rock Phospat & Dosis 5 g/tanaman & Dosis $10 \mathrm{~g} /$ tanaman & Dosis 15 g/tanaman \\
\cline { 2 - 4 } & $P 1$ & $P 2$ & $P 3$ \\
\hline $\begin{array}{c}\text { Bibit } \\
\text { kelapa sawit } \\
\text { (Pre-nursery) }\end{array}$ & $0,0500 \mathrm{~b}$ & $0,3000 \mathrm{a}$ & $0,0500 \mathrm{~b}$ \\
\hline
\end{tabular}

${ }^{{ }^{K} K e t e r a n g a n ~: ~ A n g k a ~ r a t a-r a t a ~ y a n g ~ d i ~ i k u t i ~ d e n g a n ~ h u r u f ~ y a n g ~ s a m a ~ m e n u n j u k k a n ~ t i d a k ~ b e r b e d a ~}$ nyata pada taraf alpha $5 \%$ UJI BNT $(P)=0,21$

\section{Diameter Batang Bibit Kelapa Sawit (Pre-nursery) Umur 60 dan 90 Hari Setelah Tanaman (hst)}

a. Diameter Batang Umur 60 hst

Berdasarkan hasil penelitian perlakuan kecambah bibit tanaman kelapa sawit dan pupuk rock phospat memberikan pengaruh tidak nyata pada diameter batang bibit kelapa sawit umur 60 hari setelah tanamuntuk perlakuan $\mathrm{P} 1, \mathrm{P} 2$ dan $\mathrm{P} 3$.

b. Diameter Batang Umur 90 hst

Berdasarkan tabel 5 di atas perlakuan biji

kecambah kelapa sawit dan pupuk rock phospat diameter batang tanaman kelapa sawit umur 90 hari setelah tanam berpengaruh nyata terhadap perlakuan $\mathrm{P} 1$ dan P2. Sedangkan P2 berpengaruh beda nyata pada perlakuan $\mathrm{P} 3$, dan perlakuan $\mathrm{P} 3$ tidak berbeda nyata terhadap perlakuan $\mathrm{P} 1$.

\section{Pembahasan}

\section{Waktu Tumbuh Tunas (Hari)}

Berdasarkan sidik ragam menunjukan waktu tumbuh tunas berumur $15,16,17,18,19,20,21$ dan 22 hari setelah tanam kecambah bibit kelapa sawit dan pupuk rock phospat member pengaruh tidak nyata pada semua perlakuan tanaman kecambah biji kelapa sawit pre-nursery. Di duga kecambah bibit kelapa sawit prenursery yang tumbuh tidak memerlukan pupuk rock phospat melainkan tumbuhnya kecambah kebutuhan makanan masih terpenuhi dari cadangan makanan pada embrio biji kelapa sawit. Aswanti (2001) menambahkan pertumbuhan embrio saat perkecambahan tergantung dari ketersediaan karbohidrat, protein, dan lemak pada endosperm yang berperan dalam penyediaan zat makanan. Menurut Suriatna (1991), menyatakan bahwa pemupukan tidak akan berpengaruh bila semua unsur hara yang diperlukan oleh tanaman cukup tersedia didalam tanah sesuai kebutuhan.

\section{Jumlah Daun Bibit Kelapa Sawit (Pre- nursery) Umur 30, 60 dan 90 Hari Setelah Tanam (hst)}

Berdasarkan sidik ragam menunjukan bahwa jumlah daun kecambah bibit kelapa sawit pre-nursery berumur 30 hari setelah tanam kecambah bibit kelapa sawit dan pupuk rock phospat member pengaruh tidak nyata pada perlakuan tanaman kecambah bibit kelapa sawit. Sedangkan perlakuan kecambah bibit kelapa sawit dan rock phospat umur 60 dan 90 hari setelah tanam memberikan hasil pengaruh berbeda nyata pada semua perlakuan P1, P2 dan P3 dapat dilihat pada tabel 1 dan 2. Pengaruh tidak nyata ini diduga karena pupuk rock phospate faktor tersebut tidak mampu memacu pertumbuhan tanaman secara baik. Menurut Hardjowigeno (2007) menyatakan bahwa unsur $\mathrm{P}$ berperan dalam pembelahan dan pembentukan organ tanaman.

Sedangkan akhir penelitian jumlah daun umur 60 dan 90 berpengaruh beda nyata. Pemberian pupuk rock phosphate cenderung meningkatkan pertambahan jumlah daun bibit kelapa sawit pre-nursery pada setiap dosis perlakuan $\mathrm{P} 1, \mathrm{P} 2$ dan $\mathrm{p} 3$ 
yang diberikan. Semakin tinggi dosis pupuk rock phosphate yang diberikan, maka pertambahan jumlah daun bibit kelapa sawit akan meningkat. Pemberian pupuk rock phosphate P2 umur 60 hst dosis $10 \mathrm{~g}$ pupuk $\mathrm{RP} /$ tanaman cenderung meningkatkan ratarata 2,65 helai pertambahan jumlah daun bibit kelapa sawit dibandingkan perlakuan P1dan P3. Pemberian pupuk rock phosphate P3 umur 90 hstdosis $15 \mathrm{~g}$ pupuk $\mathrm{RP} /$ tanaman cendrung meningkat rata-rata 3,93 helai dibandingkanperlakuan p1 dan p2. Hal ini diduga pemberian pupuk rock phosphate dosis $10 \mathrm{~g} /$ tanaman dan rock phosphate dosis $15 \mathrm{~g} /$ tanaman merupakan dosis yang terbaik dalam memperbaiki sifat fisik, biologi, dan kimia pada medium tanah podsolik merah kuning sehingga menghasilkan jumlah daun bibit kelapa sawit pre-nuersery tertinggi apa bila dibandingkan dengan perlakuan lainnya. Hal ini disebabkan karena varietas unggul dan pupuk phosfat membantu dalam pertumbuhan vegetative dan metabolism tanaman sehingga mendorong terbentuknya daun. Subowo, dkk (1990) menyatakan bahwa penggunaan bahan varietas unggul dan pupuk rock phosphate dapat meningkatkan agregasi tanah, memperbaiki aerasi dan perkolasi serta membuat struktur tanah menjadi lebih remah.Prawiranata et al. (1995) menyatakan bahwa peningkatan laju fotosintesis akan diiringi dengan peningkatan jumlah daun.

\section{Tinggi Bibit Kelapa Sawit (Pre-nursery) Umur 30, 60 dan 90 Hari Setelah Tanam (hst) \\ Berdasarkan sidik ragam menunjukan} Pertambahan tinggi tanaman kelapa sawit pre-nursery berumur 30 hari setelah tanam kecambah bibit kelapa sawit dan pupuk rock phospat member pengaruh tidak nyata pada perlakuan tanaman kecambah bibit kelapa sawit. Sedangkan perlakuan kecambah bibit kelapa sawit dan rock phospat umur 60 dan 90 hari setelah tanam memberikan hasil pengaruh berbeda nyata pada semua perlakuan P1, P2 dan P3 pada tabel 3 dan 4.

Pengaruh tidak nyata ini diduga karena pupuk rock phospat faktor tersebut tidak mampu memacu pertumbuhan tanaman secara baik. sesuai dengan pendapat Stell dan Torrie (1993), bahwa apabila interaksi tidak berbeda nyata maka disimpulkan bahwa faktor-faktor bertindak bebas satu sama lainnya. Ditambahkan Novizan (2005) yang menyatakan bahwa pemupukan akan efektif jika sifat pupuk yang ditebarkan dapat menambah atau melengkapi unsur hara yang tersedia di dalam tanah.

Sedangkan akhir penelitian tinggi tanaman umur 60 dan 90 berpengaruh beda nyata, pemberian rock phosphate cenderung meningkatkan pertambahan tinggi bibit kelapa sawit pada setiap dosis perlakuan yang diberikan. Semakin tinggi dosis pupuk rock phosphate yang diberikan, maka pertambahan tinggi bibit kelapa sawit akan meningkat. Pemberian pupuk dosis $15 \mathrm{~g}$ pupuk RP/tanaman Rock Phosphate umur 60 hst P3 berpengaruh beda nyata rata-rata $19,65 \mathrm{~cm}$ dan umur 90 hst P3 berpengaruh beda nyata rata-rata $20,00 \mathrm{~cm}$. Hal ini diduga pemberian pupuk rock phosphate dosis $15 \mathrm{~g}$ pupuk RP/tanaman merupakan dosis yang terbaik. Hal ini menunjukkan bahwa tinggi bibit kelapa sawit diakhir penelitian telah memenuhi standar pertumbuhan bibit kelapa sawit umur 3 bulan.

Menurut Gardner, et al (1991), proses pertambahan tinggi tanaman didahului dengan terjadinya pembelahan sel, peningkatan jumlah sel dan pembesaran ukuran sel. Foth (1997) menjelaskan bahwa unsur $P$ dibutuhkan tanaman dalam pembelahan sel. Menurut Mas'ud (1997), unsur $P$ merupakan salah satu unsur hara terpenting dalam memacu pertumbuhan tanaman, jika tanaman kekurangan unsur $P$ maka akan mempengaruhi pertumbuhan secara keseluruhan terutama tinggi tanaman. Menurut Soehardjo et al. (1998) unsur $\mathrm{P}$ yang cukup akan membantu peran dan efesiensi dari penggunaan pupuk nitrogen. Selain unsur nitrogen, kalium juga berperan dalam pertumbuhan tinggi tanaman karena unsur kalium membantu metabolisme karbohidrat dan mempercepat pertumbuhan jaringan meristematik. Dengan demikian peningkatan dosis phosfate dapat meningkatkan pertumbuhan bibit kelapa sawit pada pre-nursery termasuk pertambahan tinggi bibit kelapa sawit umur 3 bulan.

\section{Diameter Batang Bibit Kelapa Sawit (Pre-nursery) Umur 60 dan 90 Hari Setelah Tanaman (hst) \\ Berdasarkan hasil penelitian perlakuan} P1, P2 dan P3 diameter batang bibit kelapa sawit pre-nursery dan pupuk rock phospat 
umur 60 hari setelah tanam memberikan pengaruh tidak berbeda nyata, diduga diameter batang yang terbentuk lebih dipengaruhi oleh faktor genetik tanaman sehingga walaupun diberi perlakuan pemupukan yang optimal tidak memberikan pengaruh yang nyata sesuai pendapat Fitter dan Hay (1991).Perbedaan respons terhadap hara adalah berkaitan dengan hereditas. Jika proses pencucian unur hara ini sangat besar maka kehilangan unsur hara yang lebih besar dibandingkan pengambilan unsur hara oleh tanaman (Rosmarkam dan Yowono, 2002).

Sedangkan diameter batang tanaman kelapa sawit per-nursery umur 90 hari setelah tanam berpengaruh beda nyata pada perlakuan P1, P2 dan P3 dapat dilihat pada tabel 5.Pemberia dosis pupuk rock phosphate yang tinggi menunjukkan pertambahan diameter umur 3 bulan menghasilkan diameter batang bibit kelapa sawit pre-nursery pada perlakuan P2 dosis $10 \mathrm{~g}$ pupuk RP/tanaman diameter batang rata-rata $0,30 \mathrm{~cm}$, sementara diameter batang bibit sudah memenuhi standar pertumbuhan bibit kelapa sawit umur 3 bulan.

Pemberian pupuk rock phospat diduga dapat meningkatkan ketersediaan unsur fosfor yang cukup tersedia, dimana unsurunsur ini berperan dalam membantu pembentukkan karbohidrat dan protein, memperkuat jaringan tanaman, dan meningkatkan ketahanan tanaman terhadap kekeringan. Pembesaran diameter batang bonggol dipengaruhi oleh ketersediaan unsur kalium. Pendapat ini didukung oleh Setyamidjaja (2006) bahwa fosfor dan kalium dapat memperbaiki pertumbuhan vegetatif tanaman seperti diameter bonggl batang. Suriatna (1988) menyatakan bahwa fosfor berfungsi untuk mempercepat perkembangan perakaran, berperan dalam proses respirasi, proses pembelahan sel dan metabolisme tanaman sehingga mendorong laju pertumbuhan tanaman diantaranya diameter bonggol batang.

\section{KESIMPULAN}

Berdasarkan hasil penelitian yang telah dilakukan dari data yang dianalisis,maka dapat didisimpulkan:

1. Waktu muncul tunas (hari) pada perlakuan $\mathrm{P} 1, \mathrm{P} 2$ dan $\mathrm{P} 3$ kecambah bibit kelapa sawit dan pupuk rock phospatet dari data analisi rancangan percobaan tidak berpengaruh beda nyata pada semua perlakuan pengamatan hari ke $15,16,17,18,19,20,21$ dan 22 hari setelah tanam.

2. Jumlah daun(helai) pada kecambah bibit kelapa sawit dan pupuk rock phospat umur 30 hst perlakuan P1,P2 dan P3 tidak berbeda nyata. Sedangkan jumlah daun umur 60 dan 90 hst perlakuan P1, P2 dan P3 memberikan pengaruh beda nyata pada jumlah daun.

3. Tinggi tanaman bibit kelapa sawit prenursery $(\mathrm{cm})$ pada kecambah bibit kelapa sawit dan pupuk rock phospat umur 30 hst perlakuan $\mathrm{P} 1, \mathrm{P} 2$ dan $\mathrm{P} 3$ tidak berbeda nyata. Sedangkan tinggi tanaman umur 60 dan 90 hst perlakuan P1,P2 dan P3 memberikan pengaruh beda nyata pada tinggi tanaman

4. Diameter batang $(\mathrm{mm})$ pada kecambah bibit kepala sawit dan pupuk rock phospate umur 60 hst perlakuan P1,P2 dan P3 tidak memberikan pengaruh beda nyata. Sedangkan umur 90 hst memberikan pengaruh beda nyata pada diameter batang perlakuan P1, P2 dan P3.

\section{SARAN}

Hasil penelitian ini menyarankan penggunaan dosis $15 \mathrm{~g}$ pupuk RP/tanaman diberikan dua kali pada bibit kelapa sawit pre-nursery selama bibit berumur 3 bulan, pemberian pupuk RP pada awal sebelum tanaman kecambah dan pertengahan bulan (1,5 bulan).

\section{DAFTAR PUSTAKA}

Aswanti, H. 2001. Pengaruh suhu dan lama perendaman terhadap perkecambahan dan pertumbuhan bibit kopi robusta (Coffea canophoora Pierre). Skripsi Fakultas Pertanian Universitas Riau. Pekanbaru. (Tidak dipublikasikan)

Fitter, A, H dan R,H,K, Hey. 1991. Fisiologi Lingkungan Tumbuhan. Gajah Mada University Press. Yogyakarta

Foth, D,N. 1997. Dasar-dasar Ilmu Tanah. Terjemahan Endang Dwi Purbayanti Dkk. UGM Press. Yogyakarta

Gardner, FP, RB Pearce, and RL Mitchell. 1991. Fisiologi Tanaman Budidaya. 
Terjemahan. Universitas Indonesia (UIpress), Jakarta. $428 \mathrm{hlm}$.

Mas'ud. 1997. Petunjuk Penggunaan Pupuk. Penebar Swadaya. Jakarta Pahan, I. 2008. Panduan Lengkap Kelapa Sawit. Penebar Swadaya. Jakarta

Novizan.2005. Petunjuk Pemupukan yang Efektif.Agromedia Pustaka. Jakarta

Nu'man, M. 2009. Pengelolaan Tenaga Kerja Perkebunan Kelapa Sawit (Elaeis guineensisJacq.) di Perkebunan PT Cipta Futura Plantation, Muara Enim, Sumatera Selatan. Skripsi. Institut Pertanian Bogor. Bogor

Rosmarkam dan Yuwono. 2002. IImu Kesuburan Tanah. Kanisius. Yogyakarta

Suriatna, S. 1988. Pupukdan Cara Pemupukan.Melton Putra. Jakarta

Subowo, J, Subagadan M, Sudjadi. 1990. Pengaruh bahan organic terhadap bibit kelapa sawit di tanah ultisol Rangkas Bitung, Jawa Barat. Pemberitaan Penelitian Tanah danPupuk.

Suriatna, S. 1988. Pupuk dan Cara Pemupukan. Melton Putra. Jakarta

Stell, G.D and Torre, J.H. 1995. Prinsip dan Psedur Statistik. P.T. Gamedia Putera Buana. Jakarta

Soehardjo, H., Harahap, R. Ishak, A. Purba, E. Lubis, S. Budiana dan Kusmahadi. 1998. Vedemecum Kelapa Sawit. PT Perkebunan Nusantara IV. BahjambiPematang Siantar, Sumatra Utara

Setyamidjaja, D. 2006. Budidaya Kelapa Sawit. Kanisius. Yogyakarta

Winarna, E.S. Sutarta, dan W. Darmosarkoro. 2003. Efektivitas aplikasi pemupukan majemuk lambat tersedia pada pembibitan kelapa sawit. Jurnal Penelitian Kelapa Sawit. 11(3): 107-115. 